\title{
Effect of Nursing Guidelines Regarding Infection Control Measures on Performance of Internship Students in Applied Medical Science College at Hafr Al-Batin
}

\author{
Sulaiman Ali Al Yousef, Ph.D \\ Department of Medical Laboratory Technology, College of Medical Applied Science, University of Dammam, \\ 1704, Hafr Al Batin-319 91, Saudi Arabia.
}

\begin{abstract}
:
Background: Improvement in the performance of health care workers is an important aspect of infection control in the health care settings. Nursing students are more exposed to infections during clinical experience so they need to improve their performance related to infection control measures.

Aim: This study was conducted to assess of knowledge, practice and attitude of internship nursing students related to infection control and its measures and explore the effect of nursing guidelines regarding infection control and its measures on their knowledge, performance and attitude of internship nursing students.

Setting and Subjects: The study was carried out in King Khalid Hospital at Hafer Al-Batin city in Kingdom Saudi Arabia on all available internship nursing students (33 students) of College of Applied medical Science, Dammam University.
\end{abstract}

Tools: collected data were divided into three parts related to sociodemographic data; assessment of knowledge, practice and attitude toward infection control and its measures.

Results: After demonstration of guidelines regarding infection control and its measures, there were significant improvement in the level of knowledge, performance and attitude of internship nursing students.

Recommendation: The periodic refresher in-service training courses should be provided to nursing students in order to keep them of updating knowledge and practice regarding infection control measures.

Key words: infection control, nursing guidelines, health care

\section{Introduction}

Infection control is a quality standard of patient's care and is essential for the well being of the patients and the safety of both patients and staff to accomplish a reduction in infection rates, an infection control program has to be given ${ }^{(1)}$. The transmission of blood borne viruses and other microbial pathogens to patients during routine health care procedures continues to occur because of the use of unsafe and improper procedures as injection, infusion, and medication practices by health care professionals in various clinical settings ${ }^{(2,3,4)}$. The risk of infection will also be influenced by the use of various medical devices, such as mechanical ventilator, urinary and central venous catheters and enteral feeding systems ${ }^{(5)}$.

Standard precautions of infection control refers to the prevention of contact with blood ,all body fluids, secretions and excretions from the body and must be used with every patients ${ }^{(6)}$. It is necessary to ensure the safety of patients as well as healthcare personnel and those who visit the health care environment ${ }^{(7,8)}$. The standard precautions include hand washing, using personal protective equipments when likely to come into contact with bodily substances e.g. gloves, gowns, aprons, and eye goggles, correct and safe disposal of sharps, in addition to correct disposal and management of infectious waste $(9,10,11)$.

Guidelines about infection control measures are one of the strategies that have used to prevent the spread of infectious diseases. The primary aim of these guidelines, whether in the community or hospitals, is to prevent people from acquiring avoidable infection. Achieving this aim requires the willingness of all health care staff to maintain the highest possible standards of clinical practice and follow sound infection control principles (1)

Nursing student should be able to do the caring of patients after learning the principles of standard precaution, effective training is essential to ensure that these concepts about standard precautions are understood and put into practice wherever health care is provided ${ }^{(12)}$. Nurse is expected to perform all functions necessary for the total care of the patients. She must know how to protect others from contacting the disease, and she is responsible for disseminating prevention and control information to personnel, patients, their families and visitors

Nursing students have a critical role to play in the prevention efforts and they are an important population to study their level of knowledge, attitudes, and behavior regarding infection control measures, and 
obtaining this information are useful for developing programs to improve their performance ${ }^{(13,14)}$. Therefore, the purpose of the present research is to study and analyze knowledge, attitude and practices towards infection control measures among nursing internship students and to explore the effect of nursing guidelines on their knowledge, performance and attitude in order to protect themselves and others from infection transmission.

\begin{abstract}
Aim
1- Assessment of knowledge, practice and attitude of internship nursing students related to infection control and its measures.

2- Explore the effect of nursing guidelines regarding infection control and its measures on the knowledge, performance and attitude of internship nursing students.
\end{abstract}

\title{
II. Material And Methods
}

Research design: Pre and post observational design was used to carry out this study.

A-Settings: This study was carried out in Hafer Al-Batin City in Kingdom Saudi Arabia, College of Applied Medical Science, Damam University and at King Khaled Hospital during training of the internship nursing students.

B- Subjects: All available (33) nursing students were assigned to internship in the above mentioned setting was included in this study.

c- Tools for data collection: Three tools were developed by the researchers to collect the data for this study.

Tool I -Internship nursing student's knowledge regarding infection control measures structured questionnaire sheet:

Proper questionnaire was used as a tool for data collection in both pre and post test of the training guidelines, in order to measure the knowledge level of the internship nursing students about infection control measures, the questionnaire consisted of two parts;

Part(1); This questionnaire covered the demographic characteristics of internship nursing students such as: age, education, marital status. ..ect.

Part (2); the knowledge questionnaire are formulated to gather data about; infection control, hand hygiene, Personal protective equipment ( gloves, mask, gown), handling sharp instrument, staff performance, visitors, environmental hygiene, handling laboratory specimen, respiratory hygiene, safe injection practice, urinary catheter, infection control for mechanical ventilator, caring of wound dressing and giving intravenous infusion (14 items).

Scoring system of this questionnaire:-; (1) mark was given for correct answer and (zero) for wrong answer, total score for this knowledge test was (78 degrees).

\section{Tool II - Observational check list related to infection control measure;}

Observational checklist was developed for assessing nurses' performance, this tool was used before and after the guidelines to evaluate the extent to which the training guidelines affected nurses performance. Observation checklist included (13) procedure related to (hand hygiene, personal protective equipment ( gloves, mask, gown), handling sharp instrument, staff performance, visitors, environmental hygiene, handling laboratory specimen, respiratory hygiene, safe injection practice, urinary catheter, infection control for mechanical ventilator, caring of wound dressing and giving intravenous infusion). It was done during routine work.

Scoring system of nurses' performance: Total score of performance test was (118), distributed as follow: hand hygiene was (7) score, personal protective equipment was (8) score, handling sharp instrument was (9) score, staff performance was ( 11) score, visitors was (7) score, environmental hygiene was (6) score, handling laboratory specimen was (10) score, respiratory hygiene was (6) score, safe injection practice was (10)score, urinary catheter was (16) score, infection control for mechanical ventilator was (10) score, caring of wound dressing was ( 10) score, giving intravenous infusion was (8) score.

The scoring system for performance checklist:- (1) mark was given for done and (zero) for not done.

\section{Tool III -Attitude related to infection control measure;}

It includes 13 questions related to opinion of internship nursing students regarding infection control and its measures. It scored as follow: Strongly agree $=5$, Agree $=4$, Uncertain $=3$, Disagree $=2$, Strongly disagree $=1$

The questionnaires were tested for its content validity and relevance by a jury of five expertise in different fields of nursing at Tanta and Ain shams Faculty of Nursing. The experts' responses were represented in four points rating score ranging from (4-1); $4=$ strongly relevant, $3=$ relevant, $2=$ little relevant, and $1=$ not relevant. A few changes were made for a few unclear words.

The subscales' reliability values of these factors measured by Cronbach's coefficient Alpha. 


\section{IV- Nursing guidelines related to infection control measures;}

A booklet in English langauge, based on recent medical and nursing knowledge. it gives insight about standard precaution about infection control as the following;

1-Infection, infection control, hand washing, personal protective measures and handling sharp instruments

2- Environmental hygiene, precautions against blood borne transmission and prevention of respiratory infection.

3-Dealing with sharp needles, prevention of urinary infections, respiratory care for ventilator, vascular access care and handling laboratory specimen.

\section{Methods of data collection:}

Ethical consideration:

1-Explain the aim of the study to the academic coordinator of the college to take his permission to do this study with internship nursing students.

2-Explain the aim of the study to each student and take the consent from all students.

3- Assured that the obtained information will be confidential and used only for the purpose of the study.

\section{Methods:}

1-Approval for data collection was obtained from the director of Faculty of Applied Medical Science at Hafer Al-Batin for conducting the study.

2-The tools were developed by the researchers based on reviewing the recent and related literature.

3-Apilot study was conducted on 3 nurses for two weeks to ensure the reliability of the tool and to assess the student's acceptance to be involved in the study.

4-Data collection for this study was carried out in the period from October 2012 to December 2012. The methods of teaching used were lecturing followed by focus group discussions in addition to audiovisual materials, and demonstrations for practices. The details of the program and content are included in the booklet. 5-Three tools sheet were used two times. The first time was at the beginning of the study as a baseline measure before implementing guidelines and to assess the internship nursing students needs. The second time was 4 weeks after the guidelines had begun to evalute the effect of guidelines on improving intership student knowledge, practice and attitude regarding infection control and its measures.

6-Once the approval was taken to carry out the study, the researchers started to collect data and implement the program of intervention in the following way:

a-All study subjects received the three tools sheet to estimate pre-test assessment for knowledge, performance and attitude.

b- Internship nursing students are given booklet about infection control guidelines. Training sessions were conducted by the researchers which are divided into six sessions; 4 hours per day (1 day for week) for (6) weeks.

c- knowledge assessment sheet filled by the internship nursing students for pretest and post test within 30 minutes.

e-Observational checklist for assessing internship nursing students' performance was filled by the researchers within 30 minutes during the students working in the hospital.

f-Attitude sheet was filled by internship nursing students to show their attitude related to infection control and its measures within 20 minutes .

Standard precaution guidelines sessions: (National Collaborating Centre for Nursing and Supportive Care ${ }^{(15,}$ $16,17,18)$

1-The first session was geared toward theoretical knowledge content about infection, infection control, hand washing, personal protective measures and handling sharp instruments. It was given in about (4) hours.

2- The second session was geared toward clinical application of hand washing, personal protective measures and dealing with sharp instruments. It was given in about (4) hours.

3-The third session was geared toward theoretical knowledge related to; environmental hygiene, precautions against blood borne transmission and prevention of respiratory infection. It was given in about (4) hours.

4- The fourth session was geared toward clinical application of environmental hygiene, precautions against blood borne transmission and prevention of respiratory infection. It was given in about (4) hours.

5-The fifth session was geared toward theoretical knowledge related to; dealing with sharp instruments, prevention of urinary infections, respiratory care for ventilator, vascular access care and handling laboratory specimen. It was given in about (4) hours.

6-The sixth session was geared toward clinical application of dealing with sharp instruments, prevention of urinary infections, respiratory care for ventilator, vascular access care and handling laboratory specimen. It was given in about (4) hours. 
7- The total time needed for monitoring the three activities for each internship nursing students consumed about 80 minutes.

8- Evaluation of infection control guidelines was carried out by using the assessment sheet, observational checklist sheet and attitude sheet.

\section{Methods of data analysis:}

All data were collected, coded, tabulated and subjected to statistical analysis. Statistical analysis is performed by statistical Package SPSS in general (version 13), also Microsoft office Excel is used for data handling and graphical presentation. Quantitative variables are described by the Mean, Standard Deviation (SD), while qualitative categorical variables are described by proportions and percentages. Descriptive statistics are used to analyze the response to individual items and the respondents' characteristics. Chi-square and P- value test used to test correlation.

\section{Results}

Data in table (1) Shows the distribution of the studied group according to their socio-demographic characteristics. As regard to age, the table shows that the highest percentage of nurses $(60.6 \%)$ were in the age group (20-21) years old. As regard to working department, the table shows that the highest percentage of nurses $(24.2 \%)$ were working in surgical department.

Comparison between level of general knowledge about infection control for internship nursing students pre and post guidelines was clear in table (2). This table shows that there was significant improvement in general knowledge from moderate to good level post guidelines as follow; from (36.4\%) to (93.9\%) respectively.

Comparison between level of knowledge regarding general measures of infection control as (hand hygiene, personal protective equipment, handling sharp instruments, staff performance, visitors, environmental hygiene and handling laboratory specimen) for internship nursing students pre and post guidelines (Table, 3). Data shows that there was significant improvement in knowledge of general measures of infection control post guidelines at $\mathrm{P} \leq 0.05$.

Figure (1) shows comparison between level of knowledge of internship nursing students pre and post guidelines regarding specific measures of infection control which includes ( respiratory hygiene, safe injection practice, urinary catheter, infection control for mechanical ventilator, caring of wound dressing and giving intravenous infusion). This figure shows that there was significant improvement in knowledge post guidelines as follow from $(24.2,18.2,9.1,9.1,9.1,9.1 \%)$ to $(87.9,87.9,87.9,84.8,87.9,87.9 \%)$ respectively.

Table (4): Shows improvement in the total level of knowledge regarding infection control which done among studied group pre and post guidelines. This table shows that there was significant improvement in the level of total knowledge from moderate level to good level post guidelines as follow; from $(60.6 \%)$ to $(84.8 \%)$ respectively at $\mathrm{P} \leq 0.05$.

Figure (2): shows comparison between level of performance regarding general measures of infection control which includes ( hand hygiene, personal protective equipment, handling sharp instruments, staff performance, visitors, environmental hygiene and handling laboratory specimen) at internship nursing students pre and post guidelines. This figure shows that there was significant improvement in the performance post guidelines as follow from $(18.2,24.2,30.3,21.2,30.3,42.4 \%)$ to $(81.8,72.7,84.8,81.8,45.5,90.9,75.8 \%)$ respectively.

Table (5): Shows comparison between level of performance regarding specific measures of infection control which includes (respiratory hygiene, safe injection practice, urinary catheter, mechanical ventilator, wound dressing and giving intravenous infusion) for internship nursing students pre and post guidelines .This table shows that there was significant improvement in the performance post guidelines and there were highly statistically significant difference at $\mathrm{p}=\leq 0,01$.

Table (6): Shows improvement in the total level of performance which done among studied group regarding infection control pre and post guidelines. This table shows that there was significant improvement in the level of total performance from moderate level to good level post guidelines as follow; from $(60,0 \%)$ to $(84.8 \%)$ respectively at $\mathrm{P} \leq 0.05$.

Table (7): Shows the attitude of internship nursing students toward infection control. The table revealed that there was statitically significant difference between internship student nurses attitude regarding infection control and its measures pre and post guidelines and there was no difference of attitude regarding; $\mathrm{I}$ believe that my current level of knowledge about infection control is good and infection control can be improved by administrative orders and continuous observation. 
Table (1) Distribution of studied students according to their socio-demographic characteristics.

\begin{tabular}{|c|c|c|}
\hline \multirow{2}{*}{$\begin{array}{l}\text { Socio-demographic } \\
\text { characteristics }\end{array}$} & \multicolumn{2}{|c|}{$\begin{array}{l}\begin{array}{l}\text { Students } \\
(\mathrm{n}=33)\end{array} \\
\end{array}$} \\
\hline & $\mathbf{~} \mathbf{N}$ & $\%$ \\
\hline $\begin{array}{l}\text { Age: } \\
20-21 \\
22-23 \\
24-25 \\
\end{array}$ & $\begin{array}{l}20 \\
11 \\
2 \\
\end{array}$ & $\begin{array}{l}60.6 \\
33.3 \\
6.1 \\
\end{array}$ \\
\hline $\begin{array}{l}\text { Rang } \\
\text { Mean } \pm \text { SD } \\
\end{array}$ & \multicolumn{2}{|c|}{$\begin{array}{l}20-25 \\
21.61 \pm 1.03 \\
\end{array}$} \\
\hline $\begin{array}{l}\text { Marital status: } \\
\text { Single } \\
\text { Married } \\
\end{array}$ & $\begin{array}{l}26 \\
7 \\
\end{array}$ & $\begin{array}{l}78.7 \\
21.3 \\
\end{array}$ \\
\hline $\begin{array}{l}\text { Department } \\
\text { FMW } \\
\text { FSW } \\
\text { PW } \\
\text { KU } \\
\text { OR } \\
\text { ER } \\
\text { OBS } \\
\end{array}$ & $\begin{array}{l}6 \\
8 \\
3 \\
7 \\
2 \\
2 \\
5 \\
\end{array}$ & $\begin{array}{l}18.2 \\
24.2 \\
9.1 \\
21.2 \\
6.1 \\
6.1 \\
15.2\end{array}$ \\
\hline $\begin{array}{l}\text { Training about infection control } \\
\text { Yes } \\
\text { No }\end{array}$ & $\begin{array}{l}29 \\
4 \\
\end{array}$ & $\begin{array}{l}87.9 \\
12.1 \\
\end{array}$ \\
\hline $\begin{array}{l}\text { In case of yes, duration } \\
\text { One day } \\
\text { Two days } \\
\text { Three days } \\
\end{array}$ & $\begin{array}{l}29 \\
0 \\
0 \\
\end{array}$ & $\begin{array}{l}100 \\
0 \\
0 \\
\end{array}$ \\
\hline
\end{tabular}

FMW (female medical ward), FSW (female surgical ward), PW (pediatric ward), KU (kidney unit), OR (operation room), ER (emergency room), OBS (obstetric unit)

Table (2) comparison between level of general knowledge regarding infection control for internship nursing students' pre and post guidelines

\begin{tabular}{|c|c|c|c|c|c|c|}
\hline \multirow{3}{*}{ Time of assessment } & \multicolumn{6}{|c|}{$\begin{array}{l}\text { Level of knowledge regarding infection control } \\
(\mathrm{n}=33)\end{array}$} \\
\hline & \multicolumn{2}{|c|}{$\begin{array}{l}\text { Poor } \\
(0-<2)\end{array}$} & \multicolumn{2}{|c|}{$\begin{array}{l}\text { Moderate } \\
(2<4)\end{array}$} & \multicolumn{2}{|c|}{$\begin{array}{l}\text { Good } \\
(4-6)\end{array}$} \\
\hline & $\mathbf{N}$ & $\%$ & $\mathbf{N}$ & $\%$ & $\mathbf{N}$ & $\%$ \\
\hline Pre-program & 1 & 3 & 20 & 60.6 & 12 & 36.4 \\
\hline Post-program & 0 & 0 & 2 & 6.1 & 31 & 93.9 \\
\hline $\mathbf{F}$ & \multicolumn{6}{|c|}{78.25} \\
\hline 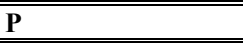 & \multicolumn{6}{|c|}{ 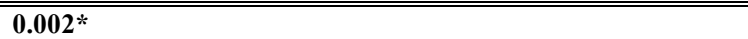 } \\
\hline
\end{tabular}

*Significant or $\mathbf{P}<\mathbf{0 . 0 5}$

Table (3) comparison between level of knowledge regarding general measures of infection control for internship nursing students' pre and post guidelines

\begin{tabular}{|c|c|c|c|c|c|c|}
\hline \multirow[t]{2}{*}{ Items } & \multicolumn{2}{|c|}{$\begin{array}{l}\text { Pre } \\
(n=33)\end{array}$} & \multicolumn{2}{|c|}{$\begin{array}{l}\begin{array}{l}\text { Post } \\
(\mathrm{n}=33)\end{array} \\
\end{array}$} & \multirow[t]{2}{*}{$\mathbf{X}^{2}$} & \multirow[t]{2}{*}{$\mathbf{P}$} \\
\hline & No & $\%$ & No & $\%$ & & \\
\hline Hand hygiene & $\frac{6^{a}}{a}$ & 18.2 & $27^{\mathrm{a}}$ & 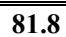 & 23.57 & $\begin{array}{l}\text { 0.032* } \\
\end{array}$ \\
\hline Personal protective equipment & $\overline{88}$ & 24.2 & 24 & $\overline{72.7}$ & 69.89 & 0.001* \\
\hline Handling sharp instruments & 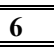 & 18.2 & 26 & 78.8 & 42.12 & 0.001* \\
\hline Staff performance & $\overline{6}$ & 18.2 & 28 & 84.8 & 42.12 & 0.013* \\
\hline Visitors & 14 & 42.4 & 28 & 84.8 & 42.57 & $0.002 *$ \\
\hline Environmental hygiene & 3 & 9.1 & 29 & 87.9 & 30.24 & $0.023 *$ \\
\hline Handling laboratory specimen & 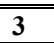 & 9.1 & 25 & 75.8 & 31.24 & $0.020 *$ \\
\hline
\end{tabular}

a No of students having knowledge in relation to total number (33) of assigned students *Significant or $\mathbf{P} \leq \mathbf{0 . 0 5}$ 
Fig (1) comparison between level of knowledge regarding specific measures of infection control for internship nursing students pre and post guidelines

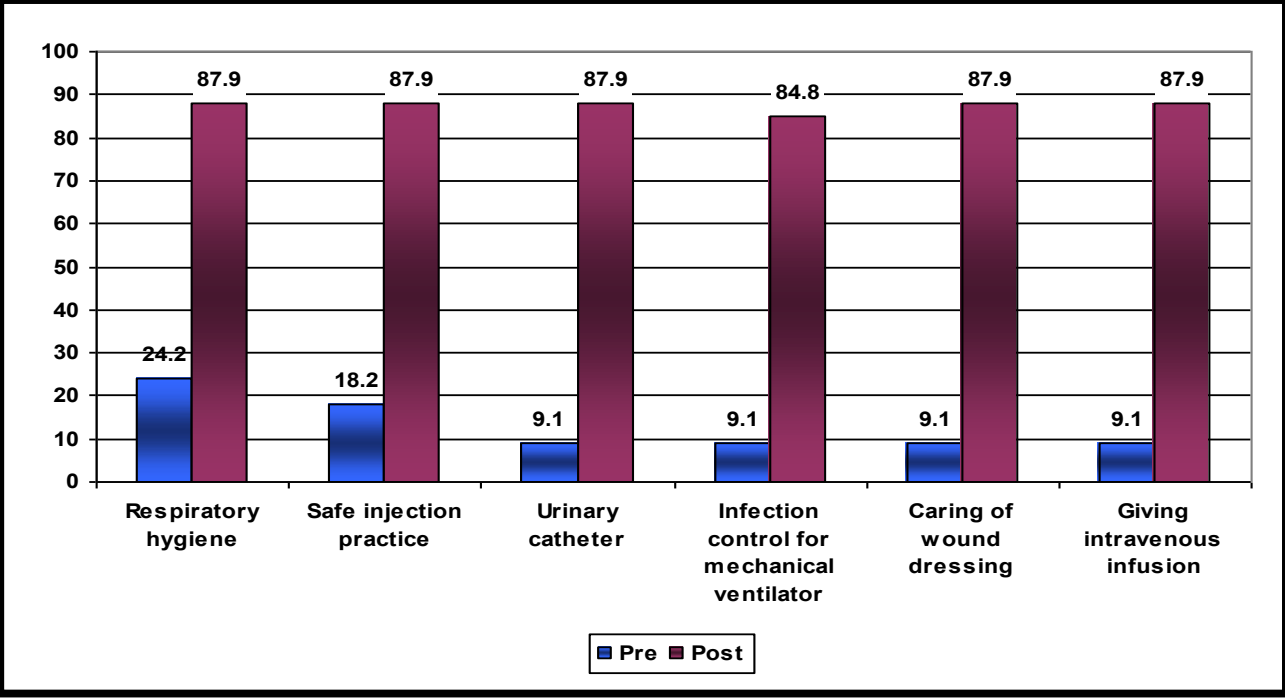

Table (4) Total level of knowledge among studied students regarding infection control at pre and post program.

\begin{tabular}{|c|c|c|c|c|c|c|}
\hline & \multicolumn{6}{|c|}{$\begin{array}{l}\text { Level of knowledge regarding specific measures of infection control } \\
(n=33)\end{array}$} \\
\hline & \multicolumn{2}{|c|}{$\begin{array}{l}\text { Poor } \\
(0-26)\end{array}$} & \multicolumn{2}{|c|}{$\begin{array}{l}\text { Moderate } \\
(17-52)\end{array}$} & \multicolumn{2}{|c|}{$\begin{array}{l}\text { Good } \\
(53-78)\end{array}$} \\
\hline & $\mathbf{N}$ & $\%$ & $\mathbf{N}$ & $\%$ & $\mathbf{N}$ & $\%$ \\
\hline Pre-program & 9 & 27.2 & 20 & 60.6 & 4 & 12.1 \\
\hline Post-program & 1 & 3 & 4 & 12.1 & 28 & 84.8 \\
\hline $\mathbf{F}$ & \multicolumn{6}{|c|}{68.25} \\
\hline $\mathbf{P}$ & \multicolumn{6}{|c|}{$0.001 *$} \\
\hline
\end{tabular}

*Significant or $\mathbf{P}<0.05$

Fig (2) comparison between level of performance regarding general measures of infection control for internship nursing students pre and post guidelines




Table (5) comparison between level of performance regarding specific measures of infection control at internship nursing students pre and post guidelines

\begin{tabular}{|c|c|c|c|c|c|c|}
\hline \multirow{2}{*}{ Items } & \multicolumn{2}{|c|}{$\begin{array}{l}\text { Pre } \\
(n=33)\end{array}$} & \multicolumn{2}{|c|}{$\begin{array}{l}\text { Post } \\
(n=33)\end{array}$} & \multirow[t]{2}{*}{$\mathrm{X} 2$} & \multirow{2}{*}{$\mathbf{P}$} \\
\hline & No & $\%$ & No & $\%$ & & \\
\hline Respiratory hygiene & $7^{a}$ & 21.2 & $20^{\mathrm{a}}$ & 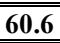 & 41.02 & $0.013^{* * *}$ \\
\hline Safe injection practice & 20 & 60.6 & 29 & 87.9 & 42.18 & $0.001 * *$ \\
\hline -Urinary catheter & 10 & 30.3 & 30 & 90.9 & 36.42 & $0.001 \% * *$ \\
\hline Mechanical ventilation & 15 & 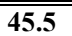 & 27 & 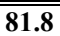 & 39.47 & $0.012 * *$ \\
\hline Wound dressing & 13 & 39.4 & 28 & 84.8 & 32.13 & $0.001 \% *$ \\
\hline Giving intravenous infusion & 8 & 24.2 & 28 & 84.8 & 60.01 & $0.001 \% *$ \\
\hline
\end{tabular}

a No of students having knowledge in relation to total number (33) of assigned students

*Significant or $\mathbf{P} \leq \mathbf{0 . 0 5}$

$* *$ Highly significant, p-value $\leq \mathbf{0 . 0 1}$

Table (6) Total level of performance among studied students regarding infection control at pre and post guidelines.

\begin{tabular}{|c|c|c|c|c|c|c|}
\hline \multirow{3}{*}{ Time of assessment } & \multicolumn{6}{|c|}{$\begin{array}{l}\text { Level of performance regarding infection control } \\
(n=33)\end{array}$} \\
\hline & \multicolumn{2}{|c|}{$\begin{array}{l}\begin{array}{l}\text { Poor } \\
(0-<40)\end{array} \\
\end{array}$} & \multicolumn{2}{|c|}{$\begin{array}{l}\text { Moderate } \\
(40-<79)\end{array}$} & \multicolumn{2}{|c|}{$\begin{array}{l}\text { Good } \\
(79-118)\end{array}$} \\
\hline & $\mathbf{N}$ & $\%$ & $\mathbf{N}$ & $\%$ & $\mathbf{N}$ & $\%$ \\
\hline Pre-program & 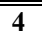 & 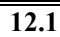 & $\overline{20}$ & 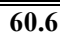 & 9 & 27.3 \\
\hline Post-program & 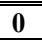 & 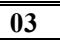 & 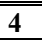 & $\overline{12.1}$ & 28 & $8 \overline{84.8}$ \\
\hline $\mathbf{F}$ & \multicolumn{6}{|c|}{$\begin{array}{l}75.25 \\
\end{array}$} \\
\hline $\bar{P}$ & \multicolumn{6}{|c|}{ 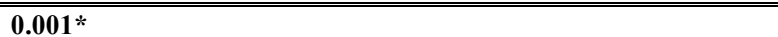 } \\
\hline
\end{tabular}

*Significant or $\mathrm{P}<0.05$

Table (7) Frequency (\%) for attitude for internship nursing student toward infection control and its measures

\begin{tabular}{|c|c|c|c|c|c|c|c|c|}
\hline \multirow[t]{2}{*}{ Items statement } & \multicolumn{3}{|c|}{$\begin{array}{l}\text { Pre } \\
(\text { no }=33)\end{array}$} & \multicolumn{3}{|c|}{$\begin{array}{l}\text { Post } \\
(n=33)\end{array}$} & \multirow[t]{2}{*}{$\mathbf{X} 2$} & \multirow[t]{2}{*}{$\mathbf{P}$} \\
\hline & $\mathbf{A}$ & $\mathbf{U}$ & $\mathbf{D}$ & $\mathbf{A}$ & $\mathbf{U}$ & $\mathbf{D}$ & & \\
\hline $\begin{array}{l}\text { 1-I use Standard Precautions to protect myself } \\
\text { whenever I suspect I might be exposed to body } \\
\text { fluids }\end{array}$ & 54.5 & 6.1 & 39.4 & 6.1 & $\mathbf{0}$ & 93.9 & 27.16 & $0.012 *$ \\
\hline $\begin{array}{l}\text { 2-I believe that my current level of knowledge } \\
\text { about infection control is good }\end{array}$ & 81.8 & $\mathbf{0}$ & 18.2 & 84.8 & $\mathbf{0}$ & 15.2 & 0.11 & 0.728 \\
\hline $\begin{array}{l}\text { 3-I frequently worry about acquiring infection } \\
\text { because of my work. }\end{array}$ & 66.6 & 6.1 & 30.3 & 90.9 & $\mathbf{0}$ & 9.1 & 29.24 & $0.011 *$ \\
\hline $\begin{array}{l}\text { 4-I try to avoid work with infected patients } \\
\text { because I fear from infection }\end{array}$ & 84.8 & 6.1 & 9.1 & 18.2 & $\mathbf{0}$ & 84.8 & 33.27 & $0.025 *$ \\
\hline $\begin{array}{l}\text {-It is not necessary for all nurses to take infection } \\
\text { control training program }\end{array}$ & 60.6 & 9.1 & 30.3 & $\mathbf{0}$ & $\mathbf{0}$ & 100 & 34.26 & 0.001 * \\
\hline $\begin{array}{l}\text { 6-Touching someone infected with any infectious } \\
\text { disease doesn't make me uncomfortable }\end{array}$ & 33.3 & 15.2 & 51.5 & 78.8 & $\mathbf{0}$ & 21.2 & 42.16 & $0.001 *$ \\
\hline 7-I enjoy taking risks in life & 81.8 & $\mathbf{0}$ & 18.2 & 87.9 & (0 & 12.1 & 28.27 & $0.002 *$ \\
\hline $\begin{array}{l}\text { 8-In my current work place, I'm offered the } \\
\text { necessary measures to protect myself from } \\
\text { communicable respiratory disease }\end{array}$ & 48.5 & 3 & 48.5 & 87.9 & 3 & 9.1 & 36.15 & $0.012 *$ \\
\hline $\begin{array}{l}\text { 9-Hand hygiene is the single most important thing } \\
\text { to do to prevent transmission of infection }\end{array}$ & 90.9 & $\mathbf{0}$ & 9.1 & 0 & 0 & 100 & 44.28 & $0.012 *$ \\
\hline $\begin{array}{l}\text { 10-I think that Performing hand hygiene in the } \\
\text { recommended situations can reduce patient } \\
\text { mortality }\end{array}$ & 60.6 & 6.1 & 33.3 & 93.9 & 0 & 6.1 & 37.46 & $0.041^{*}$ \\
\hline $\begin{array}{l}\text { 11-I can't always perform hand hygiene in } \\
\text { recommended situations because my patient's } \\
\text { needs come first }\end{array}$ & 66.7 & 12.1 & 21.2 & 87.9 & 6.1 & 6.1 & 46.24 & $0.020 *$ \\
\hline $\begin{array}{l}\text { 12-I think that isolation is important in infection } \\
\text { control. }\end{array}$ & 69.7 & 12.1 & 18.2 & 100 & 0 & $\mathbf{0}$ & 46.31 & 0.001 * \\
\hline $\begin{array}{l}\text { 13-Infection control can be improved by } \\
\text { administrative orders and continuous observation }\end{array}$ & 78.8 & $\mathbf{0}$ & 21.2 & 93.9 & 0 & 6.1 & 41.21 & 0.002 \\
\hline
\end{tabular}

$A=\%$ strongly agree and agree, $U=\%$ uncertain and $D=\%$ strongly disagree and disagree

$*$ Significant or $\mathbf{P}<\mathbf{0 . 0 5}$ 


\section{Discussion}

Infection control is a key component of practice for all healthcare professionals, not only for their health but also to reduce nosocomial infections and thus improve the patient safety ${ }^{(19)}$. Health care workers are at increased risk of occupationally acquired infection transmitted from both blood borne pathogen, such as hepatitis C\&B and Human Immune Deficiency Virus as well as respiratory infection ${ }^{(20,21)}$. Present study was carried out to assess the knowledge, practice and attitude of internship nursing students related to infection control measures and explore the effect of nursing guidelines on their performance.

Present study results revealed that there was improvement in the nursing internship students knowledge regarding general information of infection control post guidelines (93.9\%) than pre guidelines (63.4\%) (Tab.2). Al-Hussami and Darawad ${ }^{(22)}$ supported present study results and found that low level of infection prevention knowledge of students in Jordanian nursing school pre program than post program implementation..

Present study results showed that nursing student interns reported statistical significant post guidelines improvement in their knowledge about all general measures of infection control include hand hygiene, personal protective equipments, handling sharp instruments, staff performance, visitors, environmental hygiene and handling laboratory specimen with $\mathrm{p}$ value $\leq 0.05$ (Tab. 3). This could be indicated that there was lack of knowledge regarding infection control in their nursing school courses. Al-Hussami and Darawad ${ }^{(22)}$ supported present study results and showed that the educational programs was effective in promoting participant knowledge of infection prevention measures. Also, WU et al., ${ }^{(23)}$ reported that application of such programs are beneficial in promoting nursing students knowledge of infection prevention and recommended that infection control programs should be included in nursing school curriculums.

Overall, nursing students interns in present study reported highly post guidelines improvement in their knowledge about all specific measures of infection control include respiratory hygiene, safe injection practice, urinary catheter, mechanical ventilator, caring of wound dressing and giving intravenous infusion (Fig 1). Jain et al., (24) supported the present study finding and demonstrated that considerable improvement regarding the respondents knowledge and implementation of specific infection control precautions post educational program.

Present study revealed that the majority of the nursing students interns had sigificant improvement in total knowledge (general \& specific) post guidelines from moderate level $(60.6 \%)$ to good level $(84.8 \%)(\mathrm{Tab}$ $4)$. This is supported by Turner et al., ${ }^{(25)}$ who said that the implementaion of the program about infection control was very effective in enhancing nurses total knowledge and performance.

Present study results showed that the majority of nursing students interns demonstrated post guidelines improvement in their performance regarding general measures of infection control standard precautions include hand hygiene, personal protective equipments, handling sharp instruments, environmental hygiene and handling laboratory specimen than pre guidelines (fig.2). Al-Hussami and Darawad ${ }^{(22)}$ and Rosenthal et al., (26) were supported our study finding and they found that the educational programs about the infection control precautions are significantly influenced the participants performance.

Minimal improvement in nursing internship performance regarding dealing with visitors were found in present study results post guidelines $(45.5 \%)$ than pre guidelines $(30.3 \%)$ this could be due to either lack of their awareness about the role of visitors in infection transmission or lack of rules enforced by the hospital regarding control of visitors (fig.2).

Study of our post guidelines findings demonstrated that the majority of nursing student's internship performance was improved regarding specific infection control measures including insertion \& caring of catheter, safe injection, caring of wound dressing, intravenous infusion and mechanical ventilation (Tab. 5). Most probably the low level of pre guidelines performance might be due to inadequate training for infection control measures, inadequate supply of personal protective equipments and carelessness of students. This results is hand in hand with Rosenthal et al., ${ }^{(27,28)}$ which measured the effect of education and performance feedback on specific infection control measures as central venous catheter, blood stream infection and catheter associated urinary tract infection and found that the performance feedback were effective after training program .

Present study showed that the majority of the nursing students interns had sigificant improvement in total performance (general \& specific) post guidelines from moderate level $(60.6 \%)$ to good level $(84.8 \%)(\mathrm{Tab}$ $6)$. This is supported by Assma et al., (1) who said that the majority of the nurses did not carry out or perform certain procedures in relation to infection control precaution in health care centers such as use of protective barriers e.g., gloves, mask, apron and correct disposal of needles and sharp instruments Thus, it can be argued that suggested training program is effective in improving nurses' knowledge and practice regarding infection control. .

Overall (100\%) of nursing students interns in present study finding have post program positive attitude toward infection control and its measures (table.7). The positive attitude of interns could be due to the fact that the health care workers and nursing students are at high risk for infection related to frequent patient contact. Sessa et al., ${ }^{(29)}$ support the present study finding and showed that the respondents had an extremely positive attitude toward the utility of guidelines and protocol for infection control procedures. A similar results has been 
observed in nurses working in operating theater in Italy with $96.2 \%$ agree that guidelines for infection control practice used and maintained. Singh and Purohit ${ }^{(30)}$ also consistent with present study finding and found that the respondents had a positive attitude toward infection control measures.

Our study results support the finding that application of nursing guidelines are effective for improving knowledge, practice and attitude of student nurses in any health care settings. Therefore, hospital administrators should provide support and resources in the form of education and training opportunities designed to increase the health care personnel awareness and application of infection control procedures.

\section{Conclusion and Recommendation}

Our findings reveals that the nursing guidelines used in this study helped to enhance the internship students' knowledge, practice and attitude towards standards of infection control. Faculty members can facilitate and implement infection control educational guidelines within their curricula. Such a guidelines may lead to increased nurse adherence to infection control measures and ultimately have a significant effect on reducing nosocomial infection

\section{References}

[1]. K. H. Assma, F. M. Moftah, S. M. Alaa El-Din and S. S. Bayomi, Assessment of educational training program for nurses working in maternal and child health centers in Assiut city regarding infection control, Ass. Univ. Bull. Environ. Res. 7 (2), 2004, 88-96

[2]. S. A. Dolan, M. Patrick, S. Katherine and K. M. Arias, APIC Position Paper: Safe Injection, Infusion and Medication Vial Practices In Health Care, Washington, DC: Elsevier Inc., 2010, 167-170.

[3]. M. Jacson, L. Chiarello, R. Gaynes and J. Gerberding, Nurse Staffing and Health care Associated infection; proceeding from a Working Group meeting. Journal of Nursing Administration, 32(6), 2002, 314-22.

[4]. V. D. Rosenthal, R. N. Sandra Guzman, and M. D. Christopher Crnich, impact of an infection control program among rates of ventilator associated pneumonia in Intensive care units in 2 Argentinean hospitals. American Journal of infection control, 34(2),2006, 58-63.

[5]. F. Al-Orifi, D. McGillivray, S.Tange and M. S. Kramer, Urine Culture From Bag Specimens In Young Children: Are The Risks Too High?, Journal of Pediatrics. 137(2), 2002, 221-226.

[6]. S. Mehtar, D. Shisana, T. Mosala and R. Dunbar, Infection Control Practices In Public Dental Care Services: Finding From One South African Province. Hospital Infection, 66, 2007, 65-70

[7]. National Health Science Center (). Scotland Model Infection Control Policies and National Public Health Service for Wales. Infection Control Model Policies: Standard Infection Control Precautions. 2009, 162pp.

[8]. Australian Commission On Safety And Quality In Health Care, Australian Guidelines for The Prevention and Control of Infection in Healthcare, 2010,186pp.

[9]. Australian Government Department of Health and Ageing, Australian Immunization Handbook, $9^{\text {th }}$ Ed.Canberra; Commonwealth Department of Health and Ageing, 2008, 146-151.

[10]. Centers for Disease Control and Prevention, Guideline for hand hygiene in health-care settings, MMWR, 51(RR-16), $2002,1-44$.

[11]. M. D. Koff, R. W. Loftus and C. C. Burchman, Reduction In Intraoperative Bacterial Contamination Of Peripheral Intravenous Tubing Through The Use of a novel device, Anesthesiology, 110, 2009, 978-985.

[12]. Leila M. Dehkordi and K. Tavakol, Experiences of Nursing Students in Caring of Patients in Source Isolation. Iran J Nurs Midwifery Res Winter, 16(1), 2011, 16-23.

[13]. C. G. A. Nobile, P. Montuori, E. Diaco and P. Villari, Health Care Personnel And Hand Decontamination In Intensive Care Units: Knowledge, Attitude And Behavior In Italy, Hospital Infection, si: 2002, 226-232.

[14]. M. F. Chan and M. C. Day, Investigating the knowledge, Attitudes and Practice Patterns of Operating Room Staff Towards Standard and Transmission Based Precautions: Results of A Cluster Analysis, J Clin Nurs, 17, 2008, 1051-1062.

[15]. National Collaborating Centre for Nursing and Supportive Care, Infection Control. Prevention of Healthcare-Associated Infections in Primary And Community Care. London (UK): National Institute for Clinical Excellence (NICE); Jun. $2003,257$.

[16]. Society for Healthcare Epidemiology of America (SHEA), SHEA Guidelines for Management of Healthcare Workers Who are Infected With Hepatitis B Virus, Hepatitis C Virus, And/or Human Immunodeficiency Virus. Infection Control and Hospital Epidemiology, 31(3), 2010, 55-68.

[17]. A. Berman, S. Shirlee, K. Barbara and E. Glenora, Kozier and Erb's Fundamentals of Nursing: Concepts, Process, and Practice, $8^{\text {th }}$ Edition, Pearson Prentice Hall, 2010, 390.

[18]. M. J. Hockenberry, and W. W. David, Essentials of Pediatric Nursing. $8^{\text {th }}$ Edition. Elsevier Mosby: $2010,266$.

[19]. M. Christenson, J. Hitt, G. Abott, E. Septimus and N. Iverson, Improving Patient Safety; Resource Availability and Application For Reducing The Incidence of Health Care Associated Infection, Infection Control and Hospital Epidemiology, 27(3), $2006,245-251$.

[20]. C. Drosten, S. Gunther, W. Preiser, H. Werf and S. Becker, Identification of A Novel Coronavirus In Patient With Severe Acute Respiratory Syndrome, New England Journal of Medicine, 328(20), 2003, 1977-1985.

[21]. A. Stein, T. Makarawo and M. Ahmad, A Survey Of A Doctors And Nurses Knowledge, Attitude and Compliance With Infection Control Guidelines in Birmingham Teaching Hospitals, Journal of Hospital Infection, 54(1), 2003, 68-73.

[22]. M. Al-hussami and M. Darawad, Compliance of Nursing Students with Infection Prevention Precautions:Effectiveness of a Teaching Program. American Journal of Infection Prevention, 2012, 1-5.

[23]. C. Wu, G. Gardner and A. Chang, Nursing Students Knowledge And Practice Of Infection Control Precautions; An Educational Intervention, JADV NURS, 65, 2009, 214-219.

[24]. M. Jain, V. Dorga, B. Mishra, A. Thakur and P. Loomba, Infection Control Practice Among Doctors and Nurses In A Tertiary Care Hospital, New Delhi, India, 2012, 78pp.

[25]. J. G. Turner, W. C. Booth, K. C. Brown and K. M. Williamson, National Survey of Infection Practioners Educational Needs, Am J infect cont.,18, 1990, 86-92.

[26]. V. Rosenthal, S. Guzman and N. Safdar, Reduction In Nosocomial Infection With Improved Hand Hygiene in Intensive Care Units of A Tertiary Care Hospital in Argentina, American Journal of Infection Prevention, 33(7), 2012, 392-397. 
[27]. V. Rosenthal, S. Guzman, C. Pezzotto and C. Crnich, Effect of An Infection Control Program Using Education and Performance Feedback on Rates of Intravascular Device - Associated Blood stream Infection in Intensive Care Units in Argentina, American Journal of Infection Control, 31(7), 2003, 405-409.

[28]. V. Rosenthal, S. Guzman and N. Safdar, Effect of Education and Performance Feedback on Rates of Catheter- Associated Urinary Tract Infection in Intensive Care Units Iin Argentina, Infection Control and Hospital Epidemiology, 25(1), 2004, 47-50.

[29]. A. Sessa, G. Giuseppe, L. Albano and I. Angelillo (). An Investigation of Nurses' Knowledge, Attitudes, and Practices Regarding Disinfection Procedures in Italy, BMC Infectious Diseases, 11, 2011, 148-157.

[30]. A. Singh and B. Purohit, Knowledge, Attitude And Practice Towards Infection Control Measures and its Correlation Among Dental Students in Phobal City, Central India. International Journal of Infection, 75(3), 2011, 421-427. 